\title{
Preface: Beyond China, China, China
}

China's logistics is front and centre in this book that maps and analyses the country's Belt and Road Initiative and reactions to it. This focus upon logistics provides a very different window upon the Initiative's drivers and broader ramifications. There is scope for examining how logistics has been honed as a policy tool within China, before being transformed into an export strategy referred to here as 'geologistics'. This strategy has been encapsulated by Beijing in the Initiative's policy entitled Vision and Actions on Jointly Building Silk Road Economic Belt and 21st Century Maritime Silk Road. Reflecting different approaches to logistics between China's interior and coastal regions, a distinction is made in this Vision and Actions statement between land-based planning in Eurasia and a maritime stratagem for the world's oceanic realm. This examination of the Belt and Road is buttressed by selecting a different range of tools that are applicable to studying each respective sphere and illustrating them with reference to a range of case studies. Also, the application of this double-barrelled approach allows the consideration of both geopolitical and geocultural reactions of other countries to China's geologistics actions.

This new focus has allowed me to revise my China, China, China mantra, which I first used in lectures during the late 1990s to capture the attention of postgraduate students in maritime studies at the University of Wollongong, Australia. It was even remembered some twenty years later in correspondence with one of them. This raises the issue as to how the mantra originated, the need for its subsequent revision to include India; and to suggest that attention should be shifted in the future to possibly add, at least in an Asian-Pacific regional context, Indonesia. Then attention can be shifted to the repercussions of spreading China's geologistics developments across the globe in Beijing's Belt and Road Initiative.

My original interest in the People's Republic of China took root when I visited The University of Hong Kong several years before the country's 'Open Door' policy was adopted in 1978. At the time I was in the process of switching my academic interests as an economic geographer from Southeast Asia to include Northeast Asia in a bid to accommodate the effects of the influx of Japanese capital. In 1989 this broader scope led to a request from both the World Bank and the Asian Development Bank to discuss the efficiency of state-owned transport enterprises at a meeting in Manila. Then in 1990 this resulted in a further request from the Economic Development Institute 
of the World Bank to deliver a series of lectures on multimodal transport to high-level government officials from China's air, rail, road and shipping sectors at a training centre near Beijing. As the task also involved delivering a lecture at the Maritime University of Shanghai, this opportunity provided me with an important benchmark for gauging the existing state of China's logistics system.

I did not immediately follow up this opportunity in China because my attention shifted to the prospects of Hong Kong and Taiwan serving as regional hubs for the Mainland to overcome shortcomings in its logistics system. By the mid-1990s my research interest was refocused upon integrating China into the Asia-Pacific region and analysing the country's burgeoning container shipping industry. During recurrent visits to Hong Kong much use was made of information on urban and regional transport on China held in The Chinese University of Hong Kong's Library. An added bonus was having several doctoral students and co-authors, now among the professoriate, working on China's transport history and contemporary developments. After a more intensive examination of China's history and its economic geography, I ventured into studying the country's internal transport and telecommunications infrastructure and economic development. Soon after I was rash enough to expound my thesis at a conference in Dalian, China, that the period between transport developments under Sun Yat-sen during the first two decades of the twentieth century and those under Deng Xiaoping from the late 1960s were interrelated. Afterwards, I was able to travel to Changchun and Hunchun on the China-North Korean-Russian border, and return to Beijing via Shenyang to deepen my interest in the lagging Northeast economic region.

Further study was undertaken during the early 2000s into China's transport and communications firms, and the transformation of national enterprises into global players. Also, I undertook work on Korean investment in China's Shandong province using data from the Bank of Korea. In 2006 this work enabled me to restate my China, China, China mantra to students when I became the Director of the Logistics Program at Inha University in South Korea. Opportunities to visit Xiamen University several times with my Korean colleagues from Inha University underpinned my confidence about the rise-and-rise of China. This was manifest in further studies of China's container shipping companies.

In 2006 a visit to New Delhi provided me with abundant evidence that my original China, China, China mantra needed revision to accommodate the simultaneous rise of India. There is a need, if logistics developments in the twenty-first century are to be understood, to comprehend how the two powers are involved in Eurasia and surrounding oceans. In 2011 an opportunity for pursuing this matter further occurred when I was invited by China's Transport Research Institute to join a team, under the auspices of the Asian Development 
Bank, to undertake a logistics development policy study designed to improve the country's efficiency. This task focused upon the structure, conduct and performance of China's logistics system with particular attention being paid to provincial developments in Anhui, Hunan, Sichuan and Zhejiang. Also, there was an emphasis upon drawing lessons for China from Australia, Japan, Korea and the United States. This work was developed further by identifying institutional impediments to multimodalism in China's logistics service infrastructure.

This varied research in China provided a springboard to make comparisons with logistics developments not only in Australia, Japan and Korea, but also in Canada and India. These evaluations appeared in my book entitled Asian-Pacific Rim Logistics: Global Context and Local Issues. Only a very brief mention was made in this book of the sketchy details then available on China's 'Belt and Road Initiative', at the time known as 'One Belt One Road'. Since 2013 this Initiative has captured the attention of a range of commentators leading to academic papers, numerous books, including many collections arising from forums, and even a handbook and a journal dedicated to the topic. In 2018 I analysed the Initiative's underlying economic and international relations dimensions in a paper for Asian Pacific Economic Literature. Then in 2019 I was invited to China's Zhejiang Province to gauge its prospects as a Greater Bay Area to rival San Francisco Bay. These contributions have provided the impetus for the present study, which seeks not only to consider the original group of countries covered by the Initiative but also to go beyond them and provide a framework for considering its global implications. In the process, I have changed my mantra, at least for the Asian-Pacific region, to China, India, Indonesia and then gone beyond the regional focus to trace the Initiative's repercussions across Eurasia and the rest of the world. 